\title{
Risk communication in the fight against COVID-19 in Brazil: A rhetorical analysis
}

\author{
I 1 Cícera Renata Diniz Vieira Silva, ${ }^{2}$ Osvaldo Goes Bay Júnior, \\ ${ }^{3}$ Claudia Santos Martiniano, ${ }^{4}$ Severina Alice da Costa Uchoa I
}

Abstract: The objective was to analyze the information related to the new coronavirus pandemic in Brazil, conveyed by national and state authorities, through the lens of risk communication and community engagement. This is a qualitative and reflective study, anchored in rhetorical analysis. Two groups of speeches were analyzed. The first, nationwide, subdivided into the discourse by the Presidency of the Republic of Brazil and by the Ministry of Health. The second, of the states, represented by their normative actions related to the fight against the pandemic. Some recommendations in the management of the disease have unanimous understanding. Other actions, however, do not find the same support in the national and subnational discourse, reason why the following is adopted for a more detailed analysis in this article: the organization of risk communication and community engagement; the practice of social distancing; and the use of medications to treat the disease. Risk communication is based on the premise that every public health emergency faces communication challenges and may benefit from the lessons already learned. The fact that there are different discourses among the entities of the Federation implies disorganization of information, disagreements, and a greater degree of uncertainty in the population about the disease and how to prevent it.

> Keywords: Pandemics; Coronavirus; Communication; Public Health.

\author{
${ }^{1}$ Federal University of Campina \\ Grande. Cajazeiras, Brazil \\ (renatadiniz_enf@yahoo.com.br) \\ ORCID: 0000-0002-0928-8368 \\ ${ }^{2}$ Federal University of Rio \\ Grande do Norte. Natal, Brazil \\ (osvaldobay_jr@hotmail.com). \\ ORCID: 0000-0002-1017-2346 \\ ${ }^{3}$ State University of Paraiba. \\ Campina Grande, Brazil \\ (profaclaudiamartiniano@gmail. \\ com). \\ ORCID: 0000-0001-6662-6610 \\ ${ }^{4}$ Federal University of Rio \\ Grande do Norte. Natal, Brazil \\ (alicedacostauchoa@gmail.com). \\ ORCID: 0000-0002-2531-9937
}

Recebido em: 29/06/2020 Aprovado em: 08/01/2021 Revisado em: 24/05/2021 


\section{Introduction}

At the end of 2019, in Wuhan, China, there were several cases of pneumonia caused by a type of coronavirus, previously unknown (CHAN et al., 2020). Currently, there are six identified types of this virus, $\mathrm{HCoV}-229 \mathrm{E}, \mathrm{HCoV}$ OC43, HCoV-NL63, HCoV-HKU1 and SARS-COV, all causative agents of respiratory syndromes in human beings. However, the pandemic we are experiencing is related to a new type, SARS-CoV-2, the causative agent of the COVID-19 disease (PAHO, 2020a). On January 30 ${ }^{\text {th }}$, 2020, the World Health Organization (WHO) declared that COVID-19 constitutes a Public Health Emergency of International Importance (PHEII) (WHO, 2020a).

Up to date there are six PHEIIs declared by the WHO. The H1N1 influenza pandemic in 2009; the international spread of Poliovirus in 2014; the Ebola outbreak in West Africa, also in 2014; the spread of the Zika virus and increased cases of microcephaly and other congenital malformations in 2016; the Ebola outbreak in the Democratic Republic of Congo in 2018; and, currently, COVID-19 (DOMINGUEZ, 2020).

PHEIIs are part of the International Health Regulations (IHR), involving 196 countries, including Brazil (WHO, 2016). On the basis of this Regulation, after declaring COVID-19 as a public health emergency and, subsequently, as a pandemic, the WHO published the "Critical actions for preparation, readiness and response to COVID-19", a technical document containing four possible scenarios, which guides countries to prepare to respond to different public health situations: 1) Countries without cases; (2) Countries with sporadic, imported or locally detected cases; 3) Countries with groups of cases in geographically delimited locations; and 4) Countries with community transmission, i.e., disseminated (WHO, 2020b).

Worldwide, there were 9,653,048 confirmed COVID-19 cases (179,316 being new and in relation to the previous day) and 491,128 deaths (6,866 being new and in relation to the previous day) until June $27^{\text {th }}, 2020$ (PAHO, 2020b). Brazil was the first Latin American country to report the disease, on February $25^{\text {th }}, 2020$, in the city of São Paulo (BURKI, 2020) and, until June $27^{\text {th }}$, it had already recorded 1,313,667 cases and 57,070 deaths (BRASIL, 2020a).

Given this severity, and due to the rapid transformations of the communication technologies, as well as to the social, economic, political and cultural contextual 
influences, major challenges arise related to the abundance of information, whether accurate or not, which hinders people's access to reliable sources and guidelines, impairing the effectiveness of the response to public health (UN, 2020).

This phenomenon, related to the wide dissemination of all types of information, is called infodemic (WHO, 2018), which can be driven by human and non-human (bots) action, with objectives not always declared. The infodemic is also present in the COVID-19 pandemic, being catalyzed by the politicization process of the issue, which, at the same time, led to exaggeration and underestimation of the pandemic situation, as well as to a global disinformation epidemic (ZAROCOSTAS, 2020).

All the factors herein listed, as well as the significant use of social networks, cause this phenomenon to be amplified, favoring a complex co-evolution between the biological and social risks that influence perceptions and behaviors, with a significant impact on the epidemic control process, compromising the reach and sustainability of the global health system (PAHO, 2020c).

What is in evidence during the pandemic is ensuring that people do the right thing to control the disease or to mitigate its impact. In this sense, strategies are needed for the management of infodemics, Risk Communication and Community Engagement (RCCE) being an essential intervention for this (PAHO, 2020d).

RCCE involves recommendations developed by the WHO for government leaders for the preparation, readiness and response to the ongoing pandemic. In this sense, the communication component is important to generate trust and increase the probability that the health guidelines will be followed. It also minimizes and handles rumors and misunderstandings that undermine responses and can lead to greater spread of the disease (PAHO, 2020d).

It is up to the health authorities to publicly communicate relevant issues regarding public health events, such as complexity, uncertainty and health risks. In addition, this responsible practice should be capable of enhancing the credibility of the population and of being a reliable source of true information (VILELLA, 2016).

In Brazil, disinformation and the infodemic have been driven by the governmental divergences, catalyzed by a political and ideological component, producing often contradictory statements that undermine compliance, trust and consolidation of the risk communication strategies and community engagement.

In this context, the objective of this article is to analyze the diverse information related to the new coronavirus pandemic in Brazil, conveyed by national and 
state authorities, through the lens of risk communication and international community engagement.

\section{Methodology}

This is a qualitative and reflective study, anchored in rhetorical analysis, from the perspective of Perelmen and Olbrechts-Tyteca's argumentative theory (2002), which considers not the content of the speeches, but the techniques and discursive arguments to persuade and convince adherence of minds to a thesis, recalling the speaker, the premises or assumptions, the thesis or proposal, and the audience.

Rhetorical analysis comes from the theory of influence through discourse, or effective communication theory, encompassing the means that make a speech achieve its goals. Its source (corpus) can be a verbal/written document, non-verbal or both (DITTRICH, 2016).

This study has as its premise conducting the pandemic of the new coronavirus in Brazil, in the context of risk communication in epidemic situations, taking as an analysis point what has been communicated (techniques and discursive argument) to the population (particular audience) by the structure of the federal government and subnational spheres (speakers), compared with the international health recommendations (aimed at the universal audience, the global population), and how this design can represent a challenge in the fight against COVID-19.

According to Leach (2002), regardless of the type of discourse, whether deliberative, as in the case at hand, linked to the political sphere; or epidetic, related to contemporary themes (COVID 19), its persuasive action is evident, since it is used to shape opinions. According to the author, the rhetorical analysis of oral speeches and official papers can have very positive and enlightening effects, being in itself a discursive act, since it produces arguments about arguments.

Two groups of speeches were analyzed in this article. The first, nationwide, subdivided into the discourse by the Presidency of the Republic of Brazil and by the Ministry of Health. This distinction was necessary for the analysis since, although the information came from the same level, it followed sometimes contradictory guidelines. The second group of speeches was from the states, represented by their normative acts related to the fight against COVID-19. 
The selection of the Presidency of the Republic of Brazil's discourse was intentionally, on the YouTube video sharing site, on the Brasil Gov. TV channel, an information vehicle belonging to the federal government, whose virtual address is: http://youtube.com/user/TVNBR. The five videos on the President's official pronouncements on the new coronavirus were analyzed, delivered on March $6^{\text {th }}$, $12^{\text {th }}, 24^{\text {th }}$ and $31^{\text {th }}$ and on April 8th, 2020

In order to obtain official data from the Ministry of Health on the recommendations against COVID-19, it was decided to adopt the Epidemiological Bulletins of the SVS/MS on coronavirus as a documentary basis, which is found in the following virtual address: https://coronavirus.saude.gov.br/boletins-epidemiologicos. The Bulletins published before, in the same period, and immediately after the President of the Republic's pronouncements (between January and April) were chosen for comparison purposes, totaling a corpus of 07 Epidemiological Bulletins.

The data from the states (between March and May) were selected from the National Council of Health Secretaries (Conselho Nacional de Secretários de Saúde, CONASS) website, in a specific field of state normative acts on COVID-19, found in the following virtual site: http://www.conass.org.br/acesse-os-atosnormativos-estaduais-relacionados-a-covid-19/sites. Among the Brazilian states, it was decided to choose those in which the pandemic has been affecting more victims of illness and deaths in the population, namely: São Paulo, Rio de Janeiro and Ceará, based on the date of this study, June 2020 (BRASIL, 2020a).

To confer more emphasis to the results, journalistic and media articles were highlighted in the discussion, as well as events that temporally succeeded the facts listed in the documentary analysis of this article, since they broaden understanding of the context.

It is important to note that all the data in this study come from public information and available free of charge, thus respecting the ethical precepts set forth in Resolution No. 510 of April $7^{\text {th }}$, 2016, of the National Health Council.

\section{Results}

The national emergency response in public health in Brazil, via Risk Communication and Community Engagement, was established in the National Contingency Plan for Human Infection by the new coronavirus, as one of the measures. 
Among the Plan's recommendations, the following stand out: broad disclosure of epidemiological information and prevention and control measures for COVID-19; monitoring of social networks to clarify rumors, word of mouth and misinformation; issuing of health guidelines on infection to the general population, with the support of the official partners of the Interministerial Executive Group (Grupo Executivo Interministerial, GEI); frequent promotion of press conferences for conveying information; promotion of the approximation of the communication advisories of the different bodies that make up the GEI for discourse alignment and development of common actions (BRASIL, 2020b).

It then emerges as a challenge for the national leader, especially regarding the organization of public administration in Brazil, more specifically in health, which is governed by decentralization between the federal, state and municipal spheres.

In this sense, with the pandemic, a paradox is verified in the way of acting of the federal sphere, especially regarding the guidelines for the Federation Units, the municipalities and society, in which the Presidency of the Republic is observed diverging considerably from its Ministry of Health. The main divergences found at the beginning of the pandemic in Brazil will be presented below. Portraying these situations is fundamental, as they directly influenced the epidemiological control of COVID-19, due to polarization regarding the guidelines to be followed. 
Figure 1. Main highlights of the speeches by the President of the Republic of Brazil on the management of COVID-19, in official pronouncements.
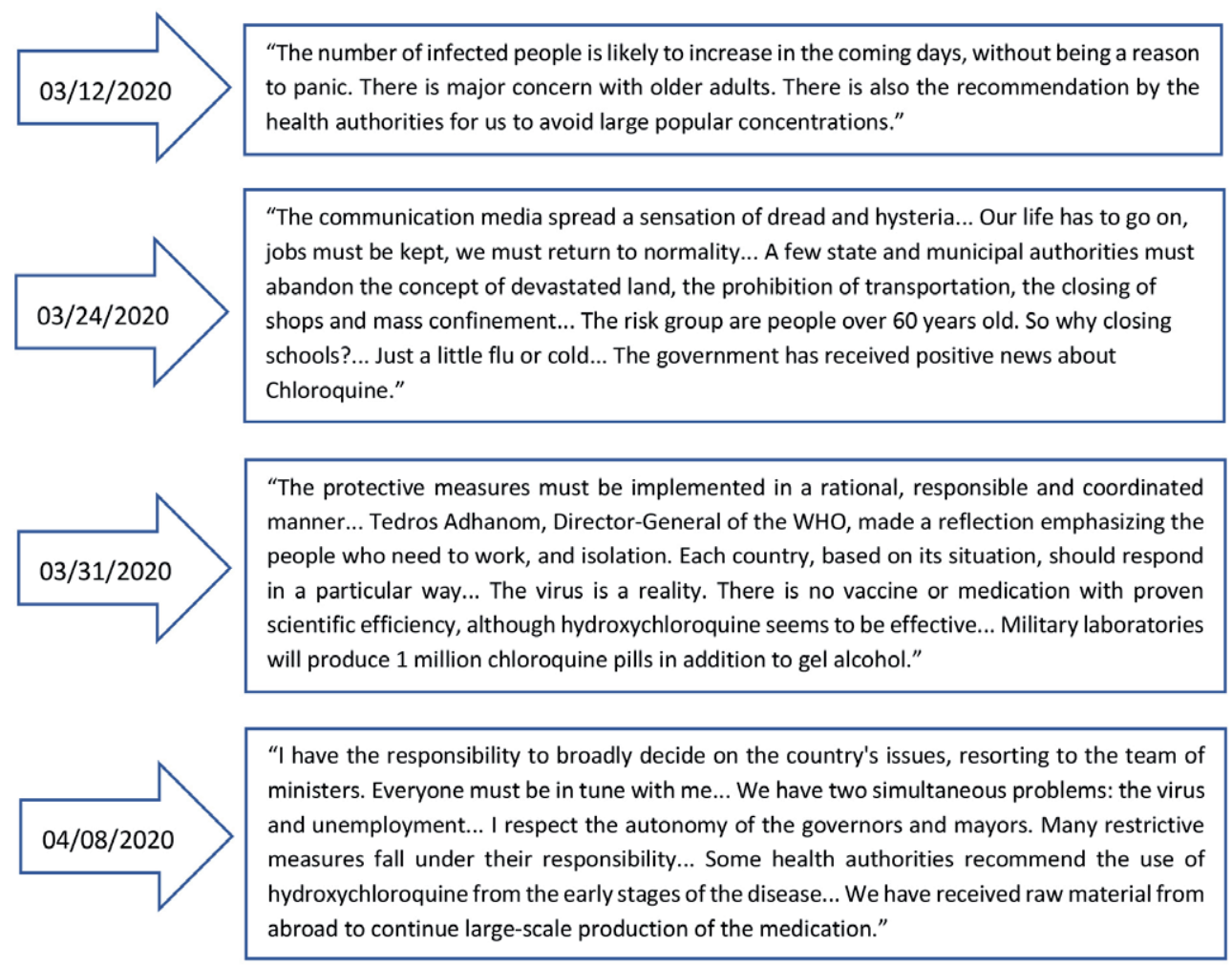

Source: Brasil Gov. TV channel Available in: https://www.youtube.com/user/TVNBR.

The discourse by the Presidency of the Republic stands out as isolated and distinct in two important and fundamental points for the current health context: social isolation and COVID-19 treatment, when compared to the international guidelines. Coming from the same federative level and in the same period, these two issues had different content in the publications by the Ministry of Health, according to Chart 1. 
Chart 1. Official publications by the Ministry of Health on social isolation and medications for COVID-19, in the same time space as the speeches by the Presidency of the Republic.

\begin{tabular}{|c|c|c|}
\hline Source & Social isolation & Treatment \\
\hline $\begin{array}{l}\text { Law No. } 13,979 \text {, } \\
\text { of February } 06^{\text {th }} \text {, } \\
\quad 2020\end{array}$ & $\begin{array}{l}\text { - National Quarantine Law. } \\
\text { - It recommends the social isolation of } \\
\text { infected people and quarantine for the } \\
\text { uninfected population as a coping measure. }\end{array}$ & - \\
\hline $\begin{array}{l}\text { Epidemiological } \\
\text { Bulletin } 01 \\
\text { (January/2020) }\end{array}$ & - & $\begin{array}{c}\text { No vaccine or specific medication } \\
\text { available }\end{array}$ \\
\hline $\begin{array}{l}\text { Epidemiological } \\
\text { Bulletin } 02 \\
(02 / 10 / 2020)\end{array}$ & - & $\begin{array}{c}\text { No vaccine or specific medication } \\
\text { available }\end{array}$ \\
\hline $\begin{array}{l}\text { Epidemiological } \\
\text { Bulletin } 03 \\
(02 / 21 / 2020)\end{array}$ & - & $\begin{array}{c}\text { No vaccine or specific medication } \\
\text { available }\end{array}$ \\
\hline $\begin{array}{l}\text { Epidemiological } \\
\text { Bulletin 05 } \\
(03 / 14 / 2020)\end{array}$ & $\begin{array}{l}\text { - Guidelines on the action plan for non- } \\
\text { pharmacological coping measures, which } \\
\text { includes home quarantine. }\end{array}$ & - \\
\hline $\begin{array}{l}\text { Epidemiological } \\
\text { Bulletin } 06 \\
(04 / 03 / 2020)\end{array}$ & $\begin{array}{l}\text { - It brings the Ministry of Health's } \\
\text { strategic objectives, the social distancing } \\
\text { strategies being essential to prevent } \\
\text { collapse of the health system. }\end{array}$ & $\begin{array}{l}\text { There is lack of scientific } \\
\text { evidence that Chloroquine may } \\
\text { be expanded to the general } \\
\text { population, without risk analysis. }\end{array}$ \\
\hline $\begin{array}{l}\text { Epidemiological } \\
\text { Bulletin } 07 \\
(04 / 06 / 2020)\end{array}$ & $\begin{array}{l}\text { - It clarifies parameters for decision- } \\
\text { making regarding the establishment of } \\
\text { the lockdown to interrupt any and all } \\
\text { activities for a given period of time. }\end{array}$ & $\begin{array}{l}\text { The Ministry of Health is } \\
\text { funding clinical studies for the } \\
\text { evaluation of drugs for treatment, } \\
\text { including Chloroquine. }\end{array}$ \\
\hline $\begin{array}{l}\text { Epidemiological } \\
\text { Bulletin 08 } \\
(04 / 09 / 2020)\end{array}$ & $\begin{array}{l}\text { - It offers guidelines on social distancing } \\
\text { measures (lockdown, expanded social } \\
\text { distancing and selective social distancing), } \\
\text { to reduce virus transmission. } \\
\text { - It explains that, in selective social } \\
\text { distancing, the vulnerable groups will } \\
\text { continue to have contact with infected } \\
\text { individuals. } \\
\text { - It points out that the social distancing } \\
\text { strategies are in accordance with the } \\
\text { recommendations by the WHO and the } \\
\text { MS itself. }\end{array}$ & $\begin{array}{l}\text { There is lack of scientific } \\
\text { evidence that Chloroquine may } \\
\text { be expanded to the general } \\
\text { population, without risk analysis. }\end{array}$ \\
\hline
\end{tabular}

Source: Own elaboration, based on the regulations, available in: http://www.planalto.gov.br/CCIVIL_03/ Portaria/quadro_portaria.htm and on the epidemiological bulletins, available in: https://coronavirus. saude.gov.br/boletins-epidemiologicos. 
In relation to the communications from the states during the pandemic, especially with regard to the measures they adopted to promote and recommend social distancing, such as quarantine and isolation of contacts, agreement is noticed with the international health recommendations and aligned with the Ministry of Health's discourse.

Table 2 depicts some of the normative acts that support in their jurisdiction social isolation in three states, with higher numbers of cases and deaths due to COVID-19, at the time of this study.

Chart 2. State Normative Acts that include social restriction measures as a way to prevent the spread of the infection by COVID-19.

\begin{tabular}{|c|c|c|}
\hline State & Normative Acts & Content \\
\hline \multirow{5}{*}{$\begin{array}{l}\text { São } \\
\text { Paulo }\end{array}$} & $\begin{array}{l}\text { - Decree No. 64,881 - } \\
\text { March } 22^{\text {nd }}, 2020 .\end{array}$ & $\begin{array}{l}\text { It decrees quarantine in the state of São } \\
\text { Paulo. }\end{array}$ \\
\hline & - Decree No. 64,920 - April 06 ${ }^{\text {th }}, 2020$. & $\begin{array}{l}\text { It extends the quarantine period adopted in } \\
\text { Decree No. 64,881 of March } 22^{\text {nd }}, 2020 .\end{array}$ \\
\hline & - Decree No. 64,946 - April 17 2020. & $\begin{array}{l}\text { It extends the quarantine measure adopted in } \\
\text { Decree No. 64,881 of March } 22^{\text {nd }}, 2020 .\end{array}$ \\
\hline & - Decree No. 64,949 - April 23 ${ }^{\text {rd }}, 2020$ & $\begin{array}{l}\text { It re-writes Article } 4 \text { of Decree No. } 64,881 \text { of } \\
\text { March } 22^{\text {nd }}, 2020 \text {, which decrees quarantine } \\
\text { in the state of São Paulo. }\end{array}$ \\
\hline & - Decree No. 64,967 - May 08 2020. & $\begin{array}{l}\text { It extends the quarantine measure adopted in } \\
\text { Decree No. } 64,881 \text { of March } 22^{\text {nd }}, 2020 .\end{array}$ \\
\hline \multirow{5}{*}{$\begin{array}{l}\text { Rio de } \\
\text { Janeiro }\end{array}$} & - Decree No. 46,973 - March 16 $6^{\text {th }}, 2020$. & $\begin{array}{l}\text { It acknowledges the emergency situation } \\
\text { and adopts measures to cope with the spread } \\
\text { resulting from the new coronavirus. }\end{array}$ \\
\hline & - Decree No. 46,980 - March 19 2020. & $\begin{array}{l}\text { It updates the measures to cope with the } \\
\text { spread resulting from the new coronavirus. }\end{array}$ \\
\hline & - Decree No. 46,983 - March 20 2020. & $\begin{array}{l}\text { It expands the measures to cope with the } \\
\text { spread resulting from the new coronavirus. }\end{array}$ \\
\hline & - Decree No. 47,006 - March 27 2020. & $\begin{array}{l}\text { It provides on measures to cope with the } \\
\text { spread resulting from the new coronavirus. }\end{array}$ \\
\hline & - Decree No. 47,027 - April 13 ${ }^{\text {th }}, 2020$. & $\begin{array}{l}\text { It provides on measures to cope with the } \\
\text { spread resulting from the new coronavirus. }\end{array}$ \\
\hline
\end{tabular}

to be continued... 


\begin{tabular}{|c|c|c|}
\hline State & Normative Acts & Content \\
\hline \multirow{5}{*}{ Ceará } & - Decree No. 33,519, March 19 ${ }^{\text {th }}, 2020$. & $\begin{array}{l}\text { It intensifies the measures to cope with } \\
\text { infection by the new coronavirus. }\end{array}$ \\
\hline & - Decree No. 33,530, March $28^{\text {th }}, 2020$ & $\begin{array}{l}\text { It extends the measures adopted in Decree } \\
\text { No. } 30,519 \text { of March } 19^{\text {th }}, 2020 \text {, and } \\
\text { subsequent amendments. }\end{array}$ \\
\hline & - Decree No. 33,536, April 05 $5^{\text {th }}, 2020$ & $\begin{array}{l}\text { It extends the measures to cope with the } \\
\text { spread of the new coronavirus in the state of } \\
\text { Ceará. }\end{array}$ \\
\hline & - Decree No. 33,544, April 19 & $\begin{array}{l}\text { It extends, at the state level, the restrictive } \\
\text { measures to fight against COVID-19. }\end{array}$ \\
\hline & - Decree No. 33,574, May 05 ${ }^{\text {th }}, 2020$ & $\begin{array}{l}\text { It institutes a policy of rigid social isolation } \\
\text { to fight against the pandemic. }\end{array}$ \\
\hline
\end{tabular}

Source: State normative acts related to COVID-19. Available in: http://www.conass.org.br/acesse-os-atosnormativos-estaduais-relacionados-a-covid-19/.

In order to clarify what the measures adopted at the state level were, the state of São Paulo was used as an example, for it leads the ranking of disease cases in the country and, therefore, Figure 2 shows actions from the norms in a brief timeline, in the sense of social restrictions.

Figure 2. Measures referring to the actions that promote social distancing that were adopted by the government of São Paulo to fight against the new coronavirus, in the same time period of the speeches by the Presidency of the Republic.

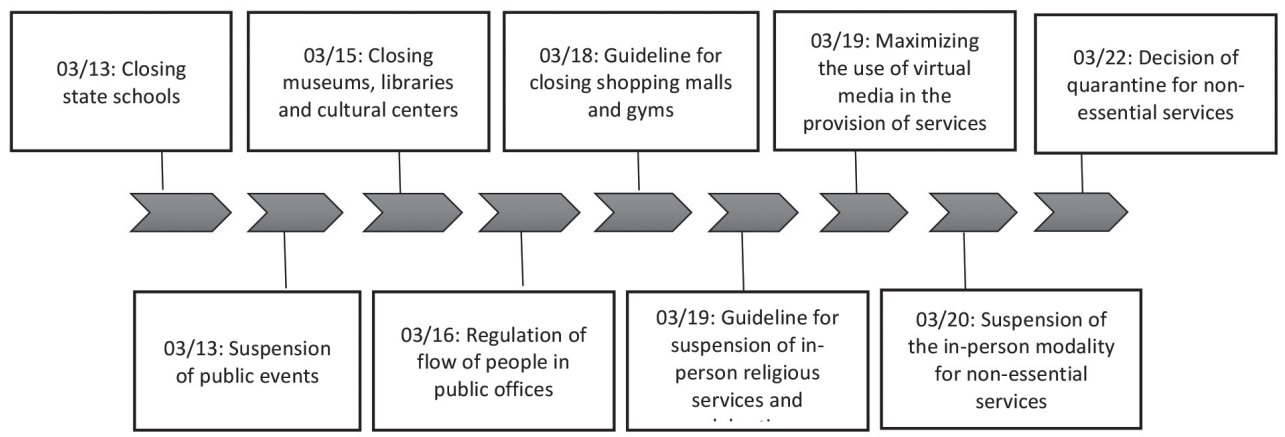

Source: Actions by the government of São Paulo. Available in: https://www.saopaulo.sp.gov.br/ 


\section{Discussion}

A rhetorical analysis on health-related topics has been used focusing on relevant issues such as community participation (Guizardi et al., 2004); debates on abortion (RIBEIRO, 2012); globalization and health indicators (MATTA; MORENO, 2014); scientific disclosure (LIGHT et al, 2016.); and argumentation in deliberative processes in the Unified Health System (Sistema Único de Saúde, SUS) (LIMA, 2020), among others. And now, from the rhetorical analysis, we discuss risk communication in the new coronavirus pandemic scenario in Brazil.

Some recommendations on the management of COVID-19 have unanimous understanding, such as hand hygiene and adoption of respiratory etiquette. Other actions, however, do not find the same support in the national and sub-national discourse, therefore being taken for further analysis in this article, namely: The organization of risk communication and community engagement; The practice of social distancing; and The use of medications to treat the disease.

\section{The (dis)organization of risk communication in Brazil}

According to Moraes, Castiel and Vasconcellos-Silva (2017), risk communication involves management and public policy issues as to the ways in which it is generated and sustains trust (which is the information source, rather than the content of the messages) and also the processes about amplification of the interests (market) on specific forms of danger and the media's role in both processes.

The organization of risk communication in Brazil, at the national level, derived from a negationist discourse by the Presidency of the Republic, whose speech and behavior disregarded any and all international guidelines. Thus, it is observed that there is no predisposition by the Presidency of the Republic to act on reducing the harms and uncertainties of the general population. On the contrary, its discourse denies the magnitude of the disease and is aligned to those for whom the pandemic brought about negative repercussions on profit - businessmen, whose "let us work" discourse requires opening of commerce, which goes against social isolation, the only way to control the pandemic until that moment. This discourse intensifies the deep social inequalities in the country, since it has varied connotations for the different social and economic realities, especially for the Brazilian population in extreme vulnerability. 
The discourse adopted by the Presidency of the Republic only reinforces how the health sector has been treated over the past few years, particularly after approval of Constitutional Amendment No. 95, with the extreme imposition of maximum public expenditure and with the current economic policies of this government, with a reduction of investments in research and health in the country. Thus, the pandemic has intensified the crisis in health. Ironically, it is in this scenario that society realizes the importance of strengthened science and of a health system guaranteeing universality of health (WERNECK; CARVALHO, 2020).

The Presidency of the Republic's negationist discourse, when asserting that "there is no reason to panic" and that "the communication media spread a sensation of fear and hysteria", also referring to the disease as "just a little flu or cold", is also perceived internationally. The image is that of a leader whose behavior causes concern for not showing commitment to confronting coronavirus, disregarding health recommendations, and continuously participating in public acts, as informed in The Lancet Infectious Diseases (BURKI, 2020). Science also recorded the denial by the President of the pandemic severity, transmission of misleading information and contradictory messages, as well as neglect in the care provided to indigenous populations (FERRANTE; FEARNSIDE, 2020).

The Brazilian Ministry of Health operationalized the Interministerial Work Group on Public Health Emergencies of National and International Importance for monitoring the situation and for definition of action protocols to monitor SARS$\mathrm{CoV}-2$ in the country (BRASIL, 2020c). From this perspective, confrontation of such issue was organized, following the international guidelines in its contingency plan. The measures adopted and their monitoring took place in a transparent manner, through daily press conferences. However, over time, this form of communication has decreased considerably.

Upon evaluating the actions by the Center for the Coordination of Operations (CCOP) of the Crisis Committee for the Supervision and Monitoring of the COVID-19 Impacts, the Federal Court of Auditors (Tribunal de Contas da Uniāo, TCU) issued a report identifying several problems in the Committee's activities. Among them were non-definition of strategic guidelines to be pursued by all the entities and actors involved and absence of technical members from the health area in the government committee. These problems have important repercussions in combating the pandemic. The first is the harmonious relationship between the 
Presidency of the Republic and the governors. The second is the possibility of making decisions that are not based on medical and scientific issues, which can result in low effectiveness of the actions to prevent and combat the pandemic (G1, 2020).

In the states, especially those most affected by COVID-19, the discourse follows the ministerial guidance since, with Rio de Janeiro as an example, it recognizes that not taking action "might lead to a serious inconvenience to public health and accountability of their agents and the State itself due to this omission" (RIO DE JANEIRO, 2020).

In doing so, it establishes an opposition with the Presidency of the Republic which, although having presented a National Contingency Plan, does not meet the inter-federative communicative alignment recommendation, blaming the state governments for any and all harms incurred to the population due to the pandemic.

It is noted that, in risk communication in public health, the risks are generally more worrying and less acceptable, if perceived as subjected to contradictory statements from responsible sources or, even worse, from the same source (Bennett et al., 2010), as in the case of Brazil.

According to Powell and Leiss (2005), good practice in communication in risk situations is in a zone that separates two types of language: on the one hand, the "specialized evaluation" issued referring to the scientific literature, anchored in specialized knowledge on the theme and using technical terminologies and, on the other hand, the "public evaluation", where people refer to risk situations based on their daily experiences, without necessarily knowing scientific and specialized results. Therefore, when these two kinds of language distance from each other and, instead of some understandable translation of the scientific discoveries, there is a gap occupied by conflicting views found among the authorities, causing uncertainties and minimizing or denying real risks, such as what is happening in the country, there are serious problems in communication.

The Brazilian panorama still faces another challenge. The third health minister who took office during the pandemic changed the way to disclose the data concerning the aggregated number of cases and deaths due to COVID-19, by removing such information from the Ministry of Health's official site. Such attitude was harshly criticized in the national and international news, such as in the British Financial Times newspaper, which chose the following headline: "Brazil accused of concealing data on coronavirus crisis" and also describes the President 
as an "extreme-right President", who "has long been accused of underestimating the severity of the outbreak, leading to the dismissal of a Health Minister and the resignation of another, as well as to the appointment of a General without experience in public health to replace them" (UOL, 2020). After the criticism, and through a Supreme Court decision, the information on cases and deaths were again normally disclosed in the Ministry of Health's website (FOLHA DE SÃO PAULO, 2020a).

\section{Social distancing in question}

The Presidency of the Republic has held that vertical isolation should be adopted, citing the discourse that "The risk group are people over 60 years old. So why closing schools?" From this perspective, only people infected with the virus and those who belong to risk groups, among which are those with chronic diseases and older adults, should isolate themselves, under the claim that broad (horizontal) isolation would cause considerable damage to the economy and, consequently, the economic crisis and unemployment would cause greater harms to the health of the population than coronavirus itself, as mentioned by the President on other occasions (ESTADO DE MINAS, 2020). In addition to that, there has been support and participation in demonstrations with various agendas, causing agglomerations, going against the WHO recommendations and those of its own Ministry (O GLOBO, 2020).

However, it is worth noting that vertical isolation with positive results in the Brazilian context is limited, both due to the difficulty surveilling cases and contacts, because of the high proportion of asymptomatic individuals, nearly $80 \%$, and due to the absence of an established and comprehensive testing system at the beginning of the epidemic in order to enable early identification of the infected individuals (WERNECK; CARVALHO, 2020).

Regarding social isolation, following WHO guidelines, the Ministry of Health advocated that it be broadly adopted by all Brazilians (horizontal isolation), so that disease transmission was distributed over a longer period of time and, thus, allowing for the preparation of the health system at the hospital level to prevent collapse. They were so communicated to the population through the reports and Epidemiological Bulletins.

The communication mismatches between the Ministry of Health and the Presidency of the Republic of Brazil, although coming from the same governmental level, have been featured in the news and divided opinions among 
the population. Such discussions initiated an ideological division hitherto not emerging within the government.

These clashes have repercussions at the state and municipal levels, where governors and mayors find themselves faced with the need to decide on their own social distancing policies (FOLHA DE SÃO PAULO, 2020b). Thus, it is observed that in São Paulo, Rio de Janeiro and Ceará, exemplified in this study, specific actions were enacted for different sectors, in order to reduce the spread rate of the disease.

The study by Ferguson et al. (2020), in the United Kingdom, evaluated several scenarios with different population isolation strategies and concluded that, even in a scenario with a reduced peak of cases, it would still be necessary to double the number of intensive care beds available in the country to meet the demand for critically-ill patients, which would cause many deaths. In fact, this happened, for example, in Italy, in the United States and in the UK countries, where the rapid progression of cases, with vertical isolation implemented, required the introduction of stricter strategies with horizontal isolation.

In Brazil, with a gradual increase in the number of cases and deaths, as has been confirmed, associated with lower-than-recommended population diagnostic testing, it is evident that the most successful strategy would be that of horizontal isolation (TAKAHASHI et al., 2020).

Added to the social distancing measures, hand hygiene and adoption of respiratory etiquette, the use of face masks has also been recommended by the national and international health authorities (AQUINO et al., 2020). The Ministry of Health and the ANVISA issued guidelines for the use of non-professional masks, which act as physical barriers, reducing exposure and the risk of infection to the general population (ANVISA, 2020). In turn, the PAHO published a document with guidelines on the use of masks in the COVID-19 context, in which it highlighted, among other things, that an advantage in the use of this protective equipment by healthy people is the reduction in the risk of exposure to infected individuals during the "pre-symptomatic" period (PAHO, 2020e). With these guidelines, the states began issuing decrees requiring their use in public places and, yet, public displays of non-adherence were observed on the part of the President of the Republic, especially in demonstrations with crowds of people (BRASÍLIA, 2020; FOLHA DE SÃO PAULO, 2020c). 
When addressing the behavioral consequences of communication, Watzlawick, Beavin and Jackson (1973) assume that it is impossible not to communicate, that is, all behaviors, not just speech, are communication and, therefore, they affect conducts. The authors refer to verbal communication as digital forms of communication and any non-verbal expressions such as gestures, postures, expressions, attitudes, and analog communication. In this context, attention is drawn to the public displays of non-compliance by the President of the Republic regarding the use of masks and other recommended health measures during the pandemic, and how this "double talk", as it is called by the aforementioned authors as being the forwarding of the verbal content of the message through behaviors, reveal the risk of the communication that is passed on to the population.

\section{The controversy on the use of medications to treat COVID-19}

Regarding the use of medications to treat COVID-19, a new feature present in the Presidency of the Republic's speeches is to support and encourage the use of chloroquine and hydroxychloroquine, even without presenting any scientific evidence, which can be verified in the speeches, such as: "There is no vaccine or medication with proven scientific efficiency, although hydroxychloroquine seems to be effective" and also "Some health authorities recommend using hydroxychloroquine from the early stages of the disease". This behavior was contrary to a number of studies based on clinical trials that did not prove the efficacy of these medications for this purpose (GELERIS et al, 2020; BOULWARE et al, 2020).

In its concomitant epidemiological bulletins with the presidential speeches, the Ministry emphasized that there was no data proving the efficacy of the medications. More recently, on May $20^{\text {th }}$, it disclosed the guidelines for improving access of patients with COVID-19 to early medical treatment, that is, in their first days with symptoms, in the SUS scope. The document contains the classification of the disease signs and symptoms and guidance for prescribing chloroquine and hydroxychloroquine to adult patients, associated with azithromycin (BRASIL, 2020d).

After release of the aforementioned medications by the Ministry of Health, the states positioned themselves differently, some signaling that they were not going to adhere to using the drugs, especially chloroquine, for not being any favorable scientific evidence available. Others pointed out that the new Ministry of Health protocol 
would be evaluated by the local scientific committees or by the Health Secretariats to then decide whether or not they would adhere (CORREIO BRAZILIENSE, 2020).

In a note published by the National School of Public Health of the Oswaldo Cruz Foundation (FIOCRUZ, 2020), it is clarified that there is polarization or ideologization of the attitudes in relation to the use of chloroquine and hydroxychloroquine within in-favor and opposed groups, in addition to the possibility of provoking doubts in the population and indiscriminate use. It adds that the findings of international, multicenter and randomized studies are the only guarantees for the supply of safe and effective treatments for patients with COVID-19.

Non-adherence by the health ministers regarding the institution of chloroquine as a choice medication for COVID-19 resulted in the replacement of two ministers, Henrique Mandetta on April $16^{\text {th }}$ and his successor, Nelson Teich, on May $15^{\text {th }}$. Subsequently, the office was temporarily taken over by military man Eduardo Pazuello, who remains in office until the date of this study.

In addition to the pressure for a change in the protocols involving the use of chloroquine, the conflicts between the President and former ministers Henrique Mandetta and Nelson Teich were strengthened with the dissonances in the speeches related to social isolation, which revealed a critical situation due to the possible repercussions for the population regarding the best conducts for mitigating the disease. These divergences between the Chief Executive Power and the health ministers were widely reflected in the press and in national and international media (NEXO JORNAL, 2020; BBC, 2020; EL PAÍS, 2020; NEW YORK TIMES, 2020).

Such changes, in a short period of time, tend to compromise success in the fight against the pandemic, due to the discontinuity of the actions that were being developed. The following can be mentioned as examples: delays in the commissioning of field hospitals that had been built; delay in the acquisition of respirators and personal protection equipment; changes in contracts for the acquisition of inputs; layoffs of technicians working in the Ministry of Health, who had been acting in the fight against the pandemic; in addition to the disarray caused in the office due to the need for meetings to explain the operation of the SUS to novices in the subject matter, such as military men, who began to occupy strategic positions in the Ministry (VEJA, 2020). 


\section{Final considerations}

This article aimed to reflect on and rhetorically analyze the diverse information related to the new coronavirus pandemic in Brazil, conveyed by the national and state authorities, through the lens of risk communication and international community engagement.

Risk communication is based on the premise that every public health emergency faces communication challenges and may benefit from the lessons already learned. The fact that there are different discourses among the entities of the Federation implies disorganization of information, disagreements, and a greater degree of uncertainty in the population about the disease and how to prevent it.

Living in an environment where the speeches seek to achieve the truth of things, starting from different assumptions, it is expected that the doubts and certainties have the same chances of success.

In Brazil, the way to conduct risk communication that was analyzed proved to be inefficient, both for not reaching alignment of the communication activities and for not being a reliable information source. In addition to that, the health crisis created an internal political crisis in the government, evident by the attempts to direct the Executive Power in conducting the country's health policy, compromising the federal pact, instead of coordination of the national policy between the national and state spheres.

\section{References}

ANVISA. Orientaçōes gerais - Máscaras faciais de uso não profissional. Brasília: Agência nacional de Vigilância Sanitária. Disponível em: https://agenciabrasilia.df.gov.br/wp-conteudo/ uploads/2020/04/NT-M\%C3\%A1scaras-Tecido-Anvisa.pdf-2.pdf. Acesso em: 18 nov. 2020. AQUINO, E.M.L. et al. Medidas de distanciamento social no controle da pandemia de COVID-19: potenciais impactos e desafios no Brasil. Ciência \& Saúde Coletiva, v. 25 (suppl 1), p. 2423-2446, 2020.

BBC News. Coronavirus: Bolsonaro fires health minister over pandemic response. [2020]. Disponível em: https://www.bbc.com/news/world-latin-america-52316150. Acesso em: 20 nov. 2020.

BENNETT, P. et al. Understandig public responses to risk. In: BENNETT, P.; CALMAN, K.; CURTIS, S.; FISCHBACHER-SMITH, D. Risk communication and public health. London: Oxford University Press, p. 3-22, 2010. 
BOULWARE, D.R. et al. A randomized trial of hydroxychloroquine as postexposure prophylaxis for Covid-19. The New England Journal of Medicine, DOI: 10.1056/NEJMoa2016638, 2020.

BRASIL. Ministério da Saúde. Painel Coronavirus Brasil. Brasília: Ministério da Saúde, 2020a. Disponível em: https://covid.saude.gov.br/. Acesso em: 27 jun. 2020.

- Ministério da Saúde. Plano de Contingência Nacional para Infecção Humana pelo novo Coronavirus 2019-nCoV. Brasília: Ministério da Saúde, 2020b. Disponível em: https:// portalarquivos2.saude.gov.br/images/pdf/2020/fevereiro/07/plano-contingencia-coronaviruspreliminar.pdf. Acesso em: 15 jun. 2020.

- Ministério da Saúde. Ministério da Saúde lidera Grupo Interministerial no enfrentamento ao novo coronavirus. Brasília: Ministério da Saúde, 2020c. Disponível em: http:// saude.gov.br/noticias/agenciasaude/46266-grupo-interministerial-vaiatuar-no-enfrentamentoao-novo-coronavirus. Acesso em: 15 jun. 2020.

- Ministério da Saúde. Orientaçôes do Ministério da Saúde para manuseio medicamentoso precoce de pacientes com diagnóstico da COVID-19. Brasília: Ministério da Saúde, 2020d. Disponível em: https://www.saude.gov.br/images/pdf/2020/May/20/orientacoes-manuseiomedicamentoso-covid19.pdf. Acesso em: 17 jun. 2020.

BRASÍLIA. Decreto $N^{\circ} 40.648$, de 23 de abril de 2020. Determina a obrigatoriedade do uso de máscaras, no âmbito do Distrito Federal, em razão da pandemia de COVID-19, causada pelo novo coronavírus. Sistema integrado de normas jurídicas do DF, 2020. Disponível em: http:/www.sinj.df.gov.br/sinj/Norma/b7e515eba350474d85dfebff90fdac1d/ Decreto_40648_23_04_2020.html. Acesso em: 19 nov. 2020.

BURKI, T. COVID-19 in Latin America. The Lancet Infectious Diseases, v. 20, n.5, p.547548, 2020.

CHAN, J. F.W. et al. A familial cluster of pneumonia associated with the 2019 novel coronavirus indicating person-to-person transmission: a study of a family cluster. The Lancet, United Kingdom, v. 395, n. 10.223, p. 514-523, 2020.

CORREIO BRASILIENSE. Ao menos oito estados não pretendem aderir a uso geral da cloroquina. [2020]. Disponível em: https://www.correiobraziliense.com.br/app/noticia/brasil/2020/05/21/ interna-brasil,857111/ao-menos-oito-estados-nao-pretendem-aderir-a-uso-geral-da-cloroquina. shtml. Acesso em: 17 jun. 2020.

DITTRICH, I.J. Análise retórica do discurso: Reflexões téorico-metodológicas. Revista Intersecçôes, v.9, n.21, p.46-65, 2016.

DOMINGUEZ, B. Alerta global: novo coronavírus é a sexta emergência em saúde pública de importância internacional declarada pela OMS. RADIS: Comunicação e Saúde, n. 210, p.14-21, 2020. 
EL PAÍS. Bolsonaro destituye al ministro de Salud en plena crisis del coronavirus. [2020]. Disponível em: https://elpais.com/internacional/2020-04-16/el-ministro-de-salud-de-brasil-afirma-que-elpresidente-bolsonaro-lo-ha-destituido.html. Acesso em: 20 nov. 2020.

ESTADO DE MINAS. Seção - Politica. Bolsonaro volta a defender fim de isolamento em prol da economia e chama críticos de "demagogos". [2020]. Disponível em: https://www.em.com.br/ app/noticia/politica/2020/03/25/interna_politica,1132580/bolsonar o-volta-a-defender-fim-deisolamento-em-prol-da-economia.shtml. Acesso em: 20 jun. 2020.

FERGUSON, N. M. et al. Impact of non-pharmaceutical interventions (NPIs) to reduce COVID-19 mortality and healthcare demand. Imperial College London, p. 1-20, 2020.

FERRANTE, L.; FEARNSIDE, P.M. Protect Indigenous peoples from COVID-19. Science, v.368, n. 6488, p.251, 2020.

FOLHA DE SÃO PAULO. Ministério da Saúde recua e volta a divulgar integra de dados da Covid-19 após decisão do STF. [2020a]. Disponível em: https://www1.folha.uol.com.br/ equilibrioesaude/2020/06/ministerio-da-saude-recua-e-volta-a-divulgar-integra-de-dados-dacovid-19-apos-decisao-do-stf.shtml. Acesso em 20/06/2020.

- Em pronunciamento, Bolsonaro defende cloroquina e retomaembate com governadores e prefeitos. [2020b]. Disponível em: https://www1.folha.uol.com.br/poder/2020/04/ em-pronunciamento-bolsonaro-defende-cloroquina-e-volta-a-responsabilizar-governadores-eprefeitos.shtml. Acesso em: 20 jun. 2020.

. Bolsonaro e apoiadores abandonam máscara e DF ignora Decreto ao não aplicar multa. [2020c]. Disponível em: https://www1.folha.uol.com.br/poder/2020/05/bolsonaro-eapoiadores-abandonam-mascara-e-df-ignora-decreto-ao-nao-aplicar-multa.shtml. Acesso em: 19 nov. 2020.

FUNDAÇÃO OSWALDO CRUZ. ESCOLA NACIONAL DE SAÚDE PÚBLICA SERGIO AROUCA. Nota sobre o uso da cloroquinalhidroxicloroquina para o tratamento da COVID-19. Informe ENSP, 2020. Disponível em: https://www.arca.fiocruz.br/handle/icict/41337. Acesso em: 22 jun. 2020.

G1 POLÍTICA. TCU aprova relatório que aponta falta de 'diretrizes' do governo no combate ao coronavirus. [2020]. Disponível em: https://g1.globo.com/politica/noticia/2020/06/24/tcuaprova-relatorio-que-aponta-falta-de-diretrizes-do-governo-no-combate-ao-coronavirus.ghtml. Acesso em: 17 jun. 2020.

GELERIS, J. et al. Observational Study of Hydroxychloroquine in Hospitalized Patients with Covid-19. The New England Journal of Medicine, v. 382, p. 2411-2418, 2020.

GUIZARDI, F.L. et al. Participação da comunidade em espaços públicos de saúde: uma análise das conferências nacionais de saúde. Physis: Revista de Saúde Coletiva, v. 14, n. 1, p. 15-39, 2004. 
LEACH, J. Análise Retórica. In: BAUER, M.W.; GASKELL, G. Pesquisa Qualitativa com texto, imagem e som. Manual Prático. Petrópolis: Vozes, 2002.

LIMA, J.C. O papel da argumentação em processos deliberativos nas instâncias de controle social do Sistema Único de Saúde. Interface-Comunicação, Saúde, Educação, v. 24, e190495, 2020.

LUZ, M.T. et al. Retórica na divulgação científica do imaginário de vida e saúde: uma proposta metodológica de análise. Interface-Comunicação, Saúde, Educação, v. 21, n.61, p. 333-347, 2016.

MATTA, G.C.; MORENO, A.B. Saúde global: uma análise sobre as relaçôes entre os processos de globalização e o uso dos indicadores de saúde. Interface-Comunicação, Saúde, Educação, v. 18, p. 9-22, 2014.

MORAES, D.R.; CASTIEL, L.D.; VASCONCELLOS-SILVA, P.R. Micromortevida Severina? A comunicação preemptiva dos riscos. Cad. Saúde Pública, Rio de Janeiro, v. 33, n. 8, e00016017, 2017.

NEW YORK TIMES. Another Health Minister in Brazil Exits Amid Chaotic Coronavirus Response. [2020]. Disponível em: https://www.nytimes.com/2020/05/15/world/americas/ brazil-health-minister-bolsonaro.html. Acesso em: 20 nov. 2020.

NEXO JORNAL. O descompasso entre o presidente e seu Ministério da saúde. [2020]. Disponível em: https://www.nexojornal.com.br/expresso/2020/05/12/O-descompasso-entre-opresidente-e-seu-Minist\%C3\%A9rio-da-Sa\%C3\%BAde. Acesso em: 20 nov. 2020.

O GLOBO. Contrariando orientaçôes da OMS, apoiadores de Bolsonaro protestam em SP contra isolamento social. [2020]. Disponível em: https://oglobo.globo.com/brasil/contrariandoorientacoes-da-oms-apoiadores-de-bolsonaro-protestam-em-sp-contra-isolamentosocial-24366136. Acesso em: 17 jun. 2020.

ORGANIZAÇÃO DAS NAÇOES UNIDAS. La ONU contra la desinformación sobre el COVID-19 y los ataques cibernéticos. 2020. Disponível em: https://www.un.org/es/coronavirus/ articles/onu-contra-desinformacion-covid-19-ataques-ciberneticos. Acesso em: 21 jun. 2020.

ORGANIZAÇÃO MUNDIAL DE SAÚDE. Regulamento Sanitário Internacional (2005). 3.ed. Geneva: World Health Organization, 2016. Disponível em: https://apps.who.int/iris/bitstream/ handle/10665/246186/9789243580494-spa.pdf?sequence=1. Acesso em: 15 jun. 2020.

ORGANIZAÇÃO PAN-AMERICANA DA SAÚDE. OPAS/OMS. Brasil-Folha informativa - COVID-19 (doença causada pelo novo coronavirus). 2020a. Disponível em: https://www.paho. org/bra/index.php?option=com_content $\&$ view=article $\& i d=6101: \operatorname{covid} 19 \&$ Itemid $=875$. Acesso em: 15 jun. 2020.

Coronavirus disease (COVID-2019) situation reports. 2020b. Disponível em: https://www.who.int/emergencies/diseases/novel-coronavirus-2019/situation-reports. Acesso em: 27 jun. 2020. 
- Understanding the infodemic and misinformation in the fight against COVID-19. 2020c. Disponível em: https://iris.paho.org/bitstream/handle/10665.2/52052/ Factsheet-infodemic_eng.pdf?sequence=3. Acesso em: 13 jun. 2020.

- Comunicação de risco e engajamento comunitário (CREC) Prontidão e resposta ao novo coronavirus de 2019 (2019-nCoV). 2020d. Disponível em: https://www.paho.org/bra/index. php?option $=$ com_docman\&view=download $\&$ slug $=$ comunicacao - de-risco-e-engajamento comunitario-crec-prontidao-e-resposta-ao-novo-coronavirus-de-2019-2019-ncov\&Itemid=965. Acesso em: 15 jun. 2020.

. Orientação sobre o uso de máscaras no contexto da COVID-19. 2020e. Disponível em: https://iris.paho.org/bitstream/handle/10665.2/51994/OPASBRACOVID1920041_por. pdf?sequence=1\&isAllowed=y. Acesso em: 19 nov. 2020.

PERELMAN, C.; OLBRECHTS-TYTECA, L. Tratado da Argumentação. São Paulo: Martins Fontes, 2002.

POWELL, D.; LEISS, W. Um diagnóstico das falhas de comunicação sobre os riscos. In: MASSARANI, L.; MOREIRA, I.C. Terra Incógnita. A interface entre ciência e público. Rio de Janeiro: Casa da Ciência; Editora Fiocruz; 2005. p.183-202.

RIBEIRO, F.R.G. Aborto por anencefalia na mídia brasileira: análise retórica do debate entre as posiçōes" pró-escolha" e" pró-vida". Revista Brasileira de Ciência Política, n. 7, p. 83-114, 2012.

RIO DE JANEIRO. Decreto No 46.980 de 19 de março de 2020. Atualiza as medidas de enfrentamento da propagaçáo decorrente do novo coronavírus em decorrência da situação de emergência em saúde, e dá outras providências. Procuradoria Geral do Estado do Rio de Janeiro, 2020. Disponível em: https://pge.rj.gov.br/covid19/estadual/decretos. Acesso em: 25 jun. 2020.

TAKAHASHI, R. H. C. et al. Vertical social distancing policy is ineffective to contain the COVID-19 pandemic. Cad. Saúde Pública, Rio de Janeiro, v.36, n.5, e00084420, 2020.

UOL NOTÍCIAS. Seção - Coronavírus. Brasile destaque no mundo por esconder dados de mortes por COVID-19. [2020]. Disponível em: https://noticias.uol.com.br/saude/ultimas-noticias/ bbc/2020/06/08/brasil-e-destaque-no-mundo-por-esconder-dados-de-mortes-por-covid-19. htm. Acesso em: 17 jun. 2020.

VEJA. Queda de dois ministros em apenas um mês deixa Saúde à deriva. [2020]. Disponível em: https://veja.abril.com.br/politica/queda-de-dois-ministros-em-apenas-um-mes-deixa-saude-aderiva/. Acesso em: 20 nov. 2020.

VILELLA, E.F.M. Comunicação de risco versus comunicação de crise na saúde pública: o discurso das autoridades diante de uma epidemia de dengue. Rev Eletron Comun Inf Inov Saúde, v.10, n.4, p.1-11, 2016. 
WATZLAWICK, P.; BEAVIN, J.H.; JACKSON, D.J. Pragmática da Comunicação Humana. São Paulo, Editora Cultrix, 1973. 263 p.

WERNECK, G.L.; CARVALHO, M.S. A pandemia de COVID-19 no Brasil: crônica de uma crise sanitária anunciada. Cad. Saúde Pública, Rio de Janeiro, v. 36, n. 5, e00068820, 2020.

WORLD HEALTH ORGANIZATION. Managing epidemics: key facts about major deadly diseases. Geneva: World Health Organization, 2018. Disponível em: https:/apps.who.int/iris/ handle/10665/272442. Acesso em: 17 jun. 2020.

. Statement on the second meeting of the International Health Regulations (2005)

Emergency Committee regarding the outbreak of novel coronavirus (2019-nCoV). Geneva: World Health Organization, 2020a. Disponível em: https://www.who.int/news-room/detail/3001-2020-statement-on-the-second-meeting-of-the-international-health-regulations-(2005)emergency-committee-regarding-the-outbreak-of-novel-coronavirus-(2019-ncov). Acesso em: 20 jun. 2020.

. WHO Director-General's opening remarks at the media briefing on Covid-19.

Geneva: World Health Organization, 2020b. Disponível em: https://www.who.int/dg/ speeches/detail/who-director-general-s-opening-remarks-at-the-media-briefing-on-covid-19--11-march-2020. Acesso em: 13 jun. 2020.

ZAROCOSTAS, J. How to fight an infodemic. The Lancet, v. 395, n.10225, p. 676, 2020.

\section{Notes}

${ }^{1}$ This research received no funding.

${ }^{2}$ There are no conflicts of interest to declare. 


\section{Resumo}

\section{Comunicação de risco no enfrentamento da COVID-19 no Brasil: uma análise retórica}

Objetivou-se analisar as informaçóes relacionadas à pandemia do novo coronavírus no Brasil, veiculadas pelas autoridades nacionais e estaduais, pelas lentes da comunicação de risco e engajamento comunitário. Trata-se de um estudo qualitativo, reflexivo, ancorado na análise retórica. Foram analisados dois grupos de discursos. O primeiro, de âmbito nacional, subdividido em discurso da Presidência da República do Brasil e do Ministério da Saúde. O segundo, dos estados, representados por seus atos normativos relacionados ao enfrentamento da pandemia. Algumas recomendaçóes no manejo da doença têm compreensão unânime. Outras açôes, no entanto, não encontram o mesmo amparo no discurso nacional e subnacional, por esse motivo sendo tomado para análise mais detalhada nesse artigo, a saber: a organizaçáo da comunicação de risco e o engajamento comunitário; a prática de distanciamento social; e o uso de medicamentos para o tratamento da doença. A comunicação de risco parte da premissa de que toda emergência de saúde pública enfrenta desafios de comunicação e pode se beneficiar das lições aprendidas anteriormente. $\mathrm{O}$ fato da existência de discursos distintos entre os entes da federação implica na desorganização das informaçóes, desentendimentos e maior grau de incerteza da população sobre a doença e como se prevenir.

Palavras-chave: Pandemias; Coronavírus; Comunicação; Saúde pública. 